\title{
Revizyon total kalça artroplastisi endikasyonları
}

\author{
Indications for revision total hip arthroplasty
}

\author{
Bahattin Kemah, Savaş Çamur \\ Sağlık Bilimleri Üniversitesi Ümraniye Eğitim ve Araştırma Hastanesi, Ortopedi ve Travmatoloji Kliniği, İstanbul
}

\begin{abstract}
Ortopedi ve travmatoloji pratiğinde gün geçtikçe yaygınlaşan total kalça artroplasti (TKA) ameliyatlarıyla beraber revizyon cerrahisi ihtiyaçları da gün geçtikçe artmaktadır. Total kalça artroplastisi revizyon ihtiyacı son 15 yılda \%20'den fazla artmış olup, önümüzdeki $10 \mathrm{yıl}$ içinde ise bu oranın ikiye katlanması beklenmektedir. Her ne kadar implant teknolojisi ve yüzey tasarımları gelişmekte olup revizyon ihtiyaçlarını ve sürelerini ötelese de, özellikle genç ve aktif hastalara kalça artroplastisi uygulanması ile ilerleyen yıllarda da revizyon cerrahisi ihtiyaçlarının artacağı düşünülmektedir. Total kalça artroplastisinde farklı endikasyonlardan dolayı revizyon ihtiyacı doğabilir. Revizyonun gereksiniminin nedenini anlamak cerrahisindeki izlenecek yola karar vermede çok önemlidir. Aynı zamanda dünyada mevcut sağlık sistemlerinde uygulamaların paket ödemelerindeki geri ödeme kapsamlarının zorlaştırılması sonrasında revizyon cerrahilerinin endikasyonlarının yerinde ve uygunluğu daha ayrıntılı araştırılmaya başlanmıştır.
\end{abstract}

Anahtar sözcükler: total kalça artroplastisi; revizyon; endikasyon; gevşeme; enfeksiyon
T otal kalça artroplastisi (TKA), ileri dönem kalça osteoartritinin tedavisinde etkili ve uygun, ancak maliyetli bir yöntemdir. Total kalça artroplastilerinin klinik olarak 10 yıllık takiplerde başarı oranı \%90'ları aşmakla beraber revizyon ihtiyaçları da bu doğrultuda artmaktadır. ${ }^{[1]}$ Daha genç hastalarda artroplasti uygulanma sayısındaki artış ile birlikte vücut kitle indeksi (VKi) artışı gibi nedenlerle revizyon ihtiyaçları da artmaktadır. ${ }^{[2]}$

Revizyon ihtiyacı olan kalça artroplastilerinin en yaygın semptomu ağrıdır. Operasyonun ilk gününden sonra devam eden ağrının nedeni enfeksiyon, çimentosuz implantların osteointegrasyon yetersizliği ya da periprostetik kırık olabilirken; ağrısız bir dönemden sonra başlayan ağrı, kırık, aseptik gevşeme, instabilite, akut hematojen ya da kronik bir enfeksiyondan veya
Total hip arthroplasty (THA) has become a common procedure in orthopedics and traumatology practice, thus the need for revision surgery has been increasing day by day. Revision rate for THA has increased more than $20 \%$ in the last 15 years, and this rate is expected to double in the next 10 years. Although development of the implant technology and surface designs enhance the survival of the prosthesis, the need for revision surgeries is expected to increase as hip arthroplasties are being performed in younger patients. THA may require revision due to different indications, understanding the reason of revision is crucial to decide the steps for the treatment. In addition, the appropriateness of the indications for revision surgeries has began to be investigated in more detail due to the difficulties of reimbursement of the healthcare companies.

Key words: total hip arthroplasty; revision; indication; loosening; infection

iliopsoas irritasyonundan kaynaklanabilir. Ağrının lokalizasyonu tanıda önemli olup; kalça yanında ağrı, abduktor mekanizma ya da trokanterik bursit nedenli olabilirken, kasıkta ağrı kalça ekleminde intrinsik bir patolojiyi işaret eder. Gece ve istirahat ağrısı ise neoplazm ya da enfeksiyonu işaret eder. ${ }^{[2]}$

Literatürde; 439 hastayı kapsayan çalışmada sekiz yıllık bir sürede revizyona giden TKA hastalarında nedenlerin \%55'inde aseptik gevşeme, \%14'ünde instabilite, \%13'ünde implant çevresi osteoliz, \%7'sinde enfeksiyon, \%5'inde periprostetik kırık, \%3'ünde hemiartroplastiden değişim, \%1'inde implant kırı̆̆ı ve \%1'inde ise psoas sıkışması olduğu bildirilmiştir. ${ }^{[3]}$ Başka bir çalışmada, 225 hastanın altı yılık takibinde, aseptik gevşemenin $\% 51,9$, instabilitenin $\% 16,9$, enfeksiyonun da \%5,5 oranında revizyon cerrahisi ihtiyacını

İletişim / Contact: Op. Dr. Bahattin Kemah • E-posta / E-mail: bahattinkemah.md@gmail.com

ORCID iD: Bahattin Kemah, 0000-0002-4795-4309 • Savaş Çamur, 0000-0001-5899-6910 
gerektirdiği bildirilmiştir. ${ }^{[4]}$ Beş yüz otuz beş revizyon kalça hastasını içeren bir başka çalışmada ise olguların \%30,9'unun ilk iki yıl içinde revizyon cerrahisi gerektirdiği ve ilk iki yıldaki en sık nedenin enfeksiyon ile periprostetik kırık olduğu, ancak mekanik yetmezliğin ve metallozisin genel olarak en sık revizyon nedeni olduğu gösterilmiştir. ${ }^{[5]}$ Başka bir çalışmada ise erken başarısızlığın (<2 yıl) en sık nedenleri sırasıyla aseptik gevşeme, instabilite ve enfeksiyon iken; 2-5 yıl arasında ise yine aseptik gevşeme, hemiartroplastinin total artroplastiye dönüştürülmesi ve enfeksiyon yer almaktadır. ${ }^{[6]}$ Aseptik gevşeme ve osteoliz ise 5-10 yıl arasında ve 10 yıl üstü dönemde en sık revizyon cerrahisi nedenleri arasında ilk sıralarda yer alır. ${ }^{[6]}$ Netice olarak literatürde yer alan total kalça artroplasti revizyon endikasyonları değerlendirildiğinde; osteoliz (kap, stem veya her ikisi birlikte), aseptik gevşeme (kap, stem veya her ikisi birlikte), enfeksiyon, metallozis, periprostetik kırık, instabilite, polietilen insert aşınması, implant kırılması ya da parçaların ayrılması (baş-boyun ayrılması), hatalı bileşen pozisyonu ve nedeni saptanamayan ağrılar olarak karşımıza çıkmaktadır. ${ }^{[4-6]}$ Erken revizyon; steril teknik, antibiyotik profilaksisi, implant yerleşimi, hastanın eşlik eden ek hastalıkları gibi nedenler ile daha ilişkili iken, geç revizyon sıklıkla konvansiyonel polietilen üzeri metal ya da metal üzeri metal gibi implantların uzun süreli aşınması ile bağlantılıdır. ${ }^{[7-9]}$

\section{ASEPTIK GEVŞEME}

Gevşeme protezin kemikten ayrılması olup bu gevşeme çimento-kemik ya da protez-çimento ara yüzünde olabilir. Günümüzde aseptik nedenler ile protez gevşemesi halen total kalça artroplasti revizyonlarının en sık nedeni olarak gösterilmektedir. Ancak çalışmalarda her geçen 10 yılda bu neden ile yapılan revizyonların sıklığının azaldığı belirtilmektedir. ${ }^{[3,4,6]}$ Aseptik gevşeme ve osteoliz iç içe devam eden süreçlerdir. Aşınma ile oluşan debrislerin eklem boşluğundan protez-kemik ara yüzüne taşınması ile aktive olan osteoklastların kemik rezorpsiyonu yapması protezde gevşemeye neden olur. Protez osteoliz olmadan da çimentodan ayrılabilir. Gevşeme, kemik ve protez arasındaki mikro-harekete de bağlı olarak gelişebilmektedir. Gevşemenin olması ile komponentlerin dengesinin bozulması, polietilen (PE) aşınması ile oluşan parçacıklar interlökin-1, interlökin-6 ve tümör nekroz faktörü gibi enflamatuvar moleküllerin ve makrofajların aracılık ettiği bir bağışıklık tepkisi üretir, bu tepkiler osteoklast aktivasyonuna ve periprostetik kemik rezorpsiyonuna yol açar, nihayetinde ise gevşeme hızlanır. ${ }^{[7,8]}$

Aseptik gevşemenin nedenleri arasında; aşıı kilo ve aşırı fiziksel aktivite, kötü protez tasarımı ve yerleşimi yer alabilir. ${ }^{[9]}$ Gelişen triboloji, iç yüzeyine büyüme üstüne büyüme yüzey yapılarının gelişmesi ve yüksek çapraz bağlı polietilen liner kullanımının yaygınlaşması, gevşeme insidansının azalmasına neden olarak gösterilmektedir. Aseptik gevşemesinin belirlenmesinde hastanın düzenli grafi takiplerinin olması ve ilk gerçekleştirilen cerrahide ameliyat içi yerleştirilen komponentlerin stabilite derecesi önemli olmaktadır.

Haynes ve ark., yaptıkları çalışmada, aseptik gevşeme nedeni ile revizyon gerçekleştirdikleri 272 hastanın \%46,3'ünde sadece asetabular komponent, \%41,5'inde yalnızca femoral komponent, \%12,5'inde ise her iki komponentinde gevşeme olduğunu saptamışlardır. Yine osteoliz nedeniyle gerçekleştirdikleri 190 cerrahi olguda; $\% 54,7$ sadece asetabular, $\% 20$ sadece femoral ve \%25,3 ise her iki komponentte osteoliz olduğunu göstermişlerdir. ${ }^{[6]}$

Metal-metal yüzeylerden oluşan kalça artroplastileri 2006-2008 yılları arasında yaygın olarak kullanıldı, ancak yüksek komplikasyon ve revizyon oranları nedeniyle bu protezler yerini yüksek çapraz bağlı polietilen (HXLPE) inserte bıraktı. ${ }^{[10]}$ Yüksek çapraz bağlı polietilen kullanılması ile, konvansiyonel polietilene göre osteoliz ve revizyon ihtiyacı insidansı da azaldı. $^{[11]}$ Osteolize bağlı en sık gevşemeler de genellikle birinci ve ikinci kuşak konvansiyonel polietilen insert kullanılan olgularda görülmüşsürr. ${ }^{[6]}$

Aseptik gevşemeye bağlı ağrı, proteze yük vermekle uylukta ya da kasıkta oluşur. Ağrı fiziksel aktivite ve kalça rotasyonel hareketleri ile artmakla beraber, dinlenmekle geriler. Uzuvda kısalma ve antaljik yürüyüş de görülebilir. Genellikle hasta ağrısının oturma pozisyonundan ayağa kalkmakla beraber oluştuğunu söyler. Bu ağrı aynı zamanda 'başlangıç ağrısı' olarak da bilinir. ${ }^{[12]}$

Femoral komponentlerin çimentolu ve çimentosuz uygulanması ile farklı gevşeme bulguları saptanabilir. Çimentolu femoral komponentlerde görülebilen radyografik bulgular içinde kesin gevşeme bulguları; çimento kırı̆̆ı, stemde kırık, femoral komponentte çökme olarak tanımlanmış, yüksek gevşeme ihtimali olan radyolojik bulgular arasında ise kemik-çimento arası radyolusensi çizgisinin devamlılığı ve bu çizginin 2 mm'den büyük olması gösterilmiştir. ${ }^{[13]}$ Çimentosuz femoral stemlerde radyografik bulgular ise implant migrasyonu, stemin kemik temas alanında parsiyel de olsa radyo-opak çift çizgi görünümü ve kemik impant arası mesafenin artmış olması gevşeme lehine görülebilecek bulgulardır. Radyolojik bulgular, kullanılan stemin proksimal tutunumlu ya da stem (sap) boyunca tam tutunumlu olmasına göre de değişebilir. Proksimal tutunumlu stemlerde kalkar bölgesindeki dansite artışı beklenen bir bulgu iken, tam tutunumlu femoral stemlerde kemiğe olan yüklenmenin dengeli 


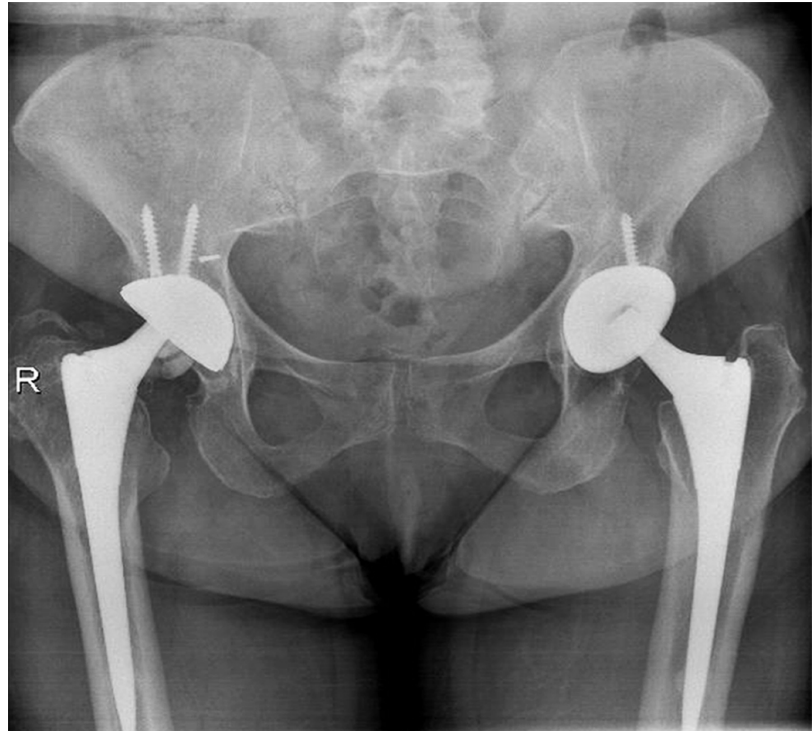

Şekil 1. Polietilen insert aşımı sonrası femur başının asetabulum içinde dış merkezli konumda durması.

olmadığını gösterir. Femur başının asetabular kap içerisinde eksantrik şekilde yerleşimi de PE (polietilen) aşınmasını gösteren radyografik bulgulardandır (Şekil 1). Femoral osteoliz olgularında cerrahi tedavi endikasyonları arasında ilerleyici lezyonlar, diyafiz osteolizisi, olası kırık ve ağrı bulunur. ${ }^{[13]}$

Çimentolu asetabular kaplarda radyolojik gevşeme bulguları içinde; kap etrafındaki çimentonun absorpsiyonu ve bu absorpsiyonun tedrici olarak devam etmesi ile $2 \mathrm{~mm}$ 'den fazla bir radyolusensinin varlığı, kapın mediale ya da superiora doğru göç etmesi, medial duvarda kırık olması, kapın inklinasyon ve anteversiyon açılarında değişiklik olması sayılabilir (Şekil 2). Çimentosuz asetabular komponentlerde ise yine kaptaki konumlanma ve açı değişiklikleri ile kemik metal yüzey arasında (kap ya da vidalar) $2 \mathrm{~mm}$ 'den fazla pelvik osteoliz saptanmasıyla radyolusensi görülmesi gevşeme lehine kabul edilebilecek bulgulardır. Kimi zaman kap etrafında kısmi gevşeme olmasıyla birkaç osteointegrasyon alanında iyi tutunum sağlaması ile, stabilitede herhangi bir kayıp olmaz ve hastanın ağrı şikâyetleri hiç olmayabilir. Bu gibi durumlarda çoğu yazara göre 3-6 ay içinde ilerleyen osteolitik lezyonların olması revizyon endikasyonu doğurmaktadır. ${ }^{[13]}$

\section{ENFEKSIYON}

Periprostetik eklem enfeksiyonu, artroplasti sonrası implantın çevresinde gelişen enfeksiyondur ve protez sonrası görülebilecek ciddi bir komplikasyondur.
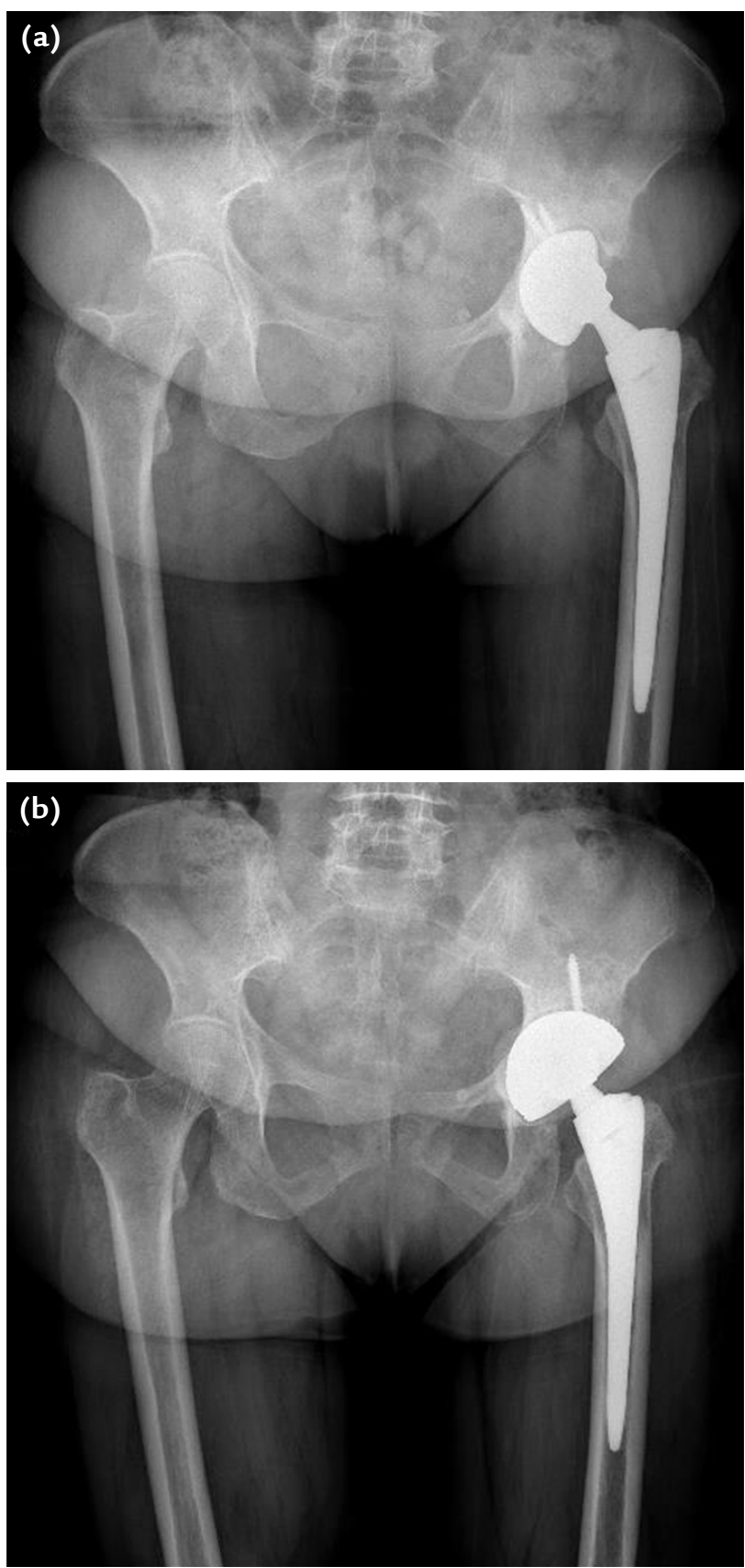

Şekil 2. a, b. Gevşemeye bağlı asetabular kap dönmesi (a), gevşemenin ilk bulguları asetabular kap kenarında lizis oluşumu (b).

Kalça artroplastisi sonrasında enfeksiyon insidansı \%1 civarındadır. Periprostetik eklem enfeksiyonlarının tarihsel süreç içerisinde farklı sınıflamaları olmuştur. Bu sınıflamalardan biri, Tsukayama'nın sınıflamasıdır: 1) Erken enfeksiyon; ameliyat sonrası ilk ay görülür. 2) Geç kronik enfeksiyon; ameliyat sonrası ilk aydan sonra başlar. 3) Akut hematojen enfeksiyon; 
postop birinci aydan sonra görülür uzak enfeksiyon kaynağı nedenlidir. 4) Ameliyat esnasında pozitif kültürler; septik olabileceği düşünülen revizyonlarda alınan kültürlerin pozitif çıkması. ${ }^{[14]}$

Protez cerrahisi sonrası görülen derin enfeksiyon, klinik gidişatı ve zamanı bakımından üçe ayrılır: 1) Akut enfeksiyon; ameliyat sonrası 6 . haftaya kadar görülen enfeksiyondur. 2) Subakut enfeksiyon; 6.-8. aya kadar gelişen enfeksiyondur; genellikle virulansı düşük mikroorganizmaların periprostetik kontaminasyonu sonucu oluşur. 3) Geç enfeksiyon ise 1. yıl sonrası görülür; hematojen ya da lenfojen yayılım ile yeni meydana gelen enfeksiyondur. ${ }^{[14]}$

Periprostetik eklem enfeksiyonu tanısını ameliyat sonrası erken dönemde koymak; ağrı, ödem ve insizyon çevresi kızarıklık gibi tam güvenilemeyecek semptomlar nedeniyle son derece güçtür. Tanıda en sık kullanılan laboratuvar testleri C-reaktif protein (CRP) ve eritrosit sedimentasyon hızı (ESR)'dır. Eritrosit sedimentasyon hızı \%91 duyarlılık ve $\% 72$ özgüllük, CRP ise \%94 duyarlılık ile \%74 özgüllük oranına sahiptir. ${ }^{[15]}$ Aynı zamanda serum testlerinin olası yalancı negatifliği de söz konusu olabilir. Periprostetik eklem enfeksiyonu olan hastaların \%2,5'inde serum testleri negatiftir. Ancak bu parametreler erken cerrahi döneminde de yüksek seviyelerde olduğu için septik komplikasyonlar açısından tam yeterli olmayabilir. Çoğu periprostetik eklem enfeksiyonu eklem aspirasyonu ve sinovyal sıvı analizi ile tanımlanır. Enfeksiyon tanısı halen netleştirilemiyorsa ameliyat esnasındaki görünüm, kültür ve histoloji örneklemelerine yeni nesil DNA dizileme bulguları dâhil edilince, periprostetik enfeksiyonların yaklaşık \%17'si teşhis edilebilir. [16]

Ameliyat sonrası ağrılı bir kalça protezi şikâyeti olan hastada ilk olarak düşünülmesi gereken komplikasyon enfeksiyondur. Enfeksiyon sonrası da hastaların en sık başvuru şikâyeti kalça ağrısı olup, bu ağrının istirahat ile devam etmesi patognomiktir. Ağrının devamlı ve gittikçe şiddeti artar nitelikte olması kuvvetli olarak enfeksiyon olasılığını düşündürmelidir. ${ }^{[14]}$

Periprostetik eklem enfeksiyonlarının tanısı için farklı dönemlerde ve kuruluşlarda çeşitli komiteler oluşturulmuş ve çalışmalar yapılmıştır. Yaygın olarak kullanılan algoritmalar, Amerikan Ortopedik Cerrahi Akademisi (AAOS) ve Uluslararası Ortak Görüş Toplantısı (ICM)'nın yayımladığı kılavuzlara dayanmaktadır (Tablo 1). ${ }^{[16]}$

Enfeksiyonun radyolojik bulguları spesifik olmamakla beraber, aşınma olmaksızın genel kemik rezorpsiyonu, periost reaksiyonu ya da odak osteoliz alanları görülebilir. ${ }^{[17]}$

Tablo 1. Periprostetik eklem enfeksiyonu kriterleri ${ }^{[16]}$

\begin{tabular}{|c|c|c|c|c|}
\hline \multicolumn{4}{|c|}{ Major kriterler (en az bir tanesinin olması) } & Sonuç \\
\hline \multicolumn{4}{|c|}{ Aynı organizmaların iki pozitif kültürü } & Enfolato \\
\hline \multicolumn{5}{|c|}{ Eklemle ilişkili sinus traktı olması ya da protezin görünür olması } \\
\hline \multirow{13}{*}{ 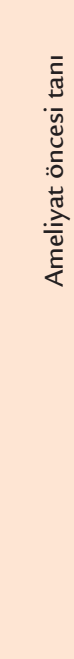 } & \multicolumn{2}{|c|}{ Minör kriterler } & Skor & Sonuç \\
\hline & \multirow{2}{*}{ ڤ్ } & Yüksek CRP veya D-Dimer & 2 & \multirow{6}{*}{$\begin{array}{l}\geq 6 \text { Enfekte } \\
2-5 \text { Enfeksiyon şüphesi } \\
0-1 \text { Enfekte değil }\end{array}$} \\
\hline & & Yüksek ESR & 1 & \\
\hline & \multirow{4}{*}{ in } & Yüksek sinovyal WBC veya Lökosit esteraz & 3 & \\
\hline & & Pozitif alfa-defensin & 3 & \\
\hline & & Yüksek sinovyal PMN (\%) & 2 & \\
\hline & & Yüksek sinovyal CRP & 1 & \\
\hline & \multirow{6}{*}{ 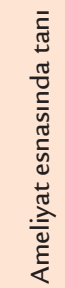 } & İşlem öncesi belirsiz durum & Skor & \multirow{6}{*}{$\begin{array}{l}\text { Sonuç } \\
\geq 6 \text { Enfekte } \\
\text { 4-5 Belirsiz } \\
\text { <3 Enfekte değil }\end{array}$} \\
\hline & & Ameliyat öncesi skor & & \\
\hline & & & & \\
\hline & & Pozitif histoloji & 3 & \\
\hline & & Pozitif pürülans & 3 & \\
\hline & & Tek kültür sonuç pozitifliği & 2 & \\
\hline
\end{tabular}

(C-reaktif protein, CRP; eritrosit sedimentasyon hızı, ESR; beyaz kan hücreleri, WBC; nötrofil, PMN) 


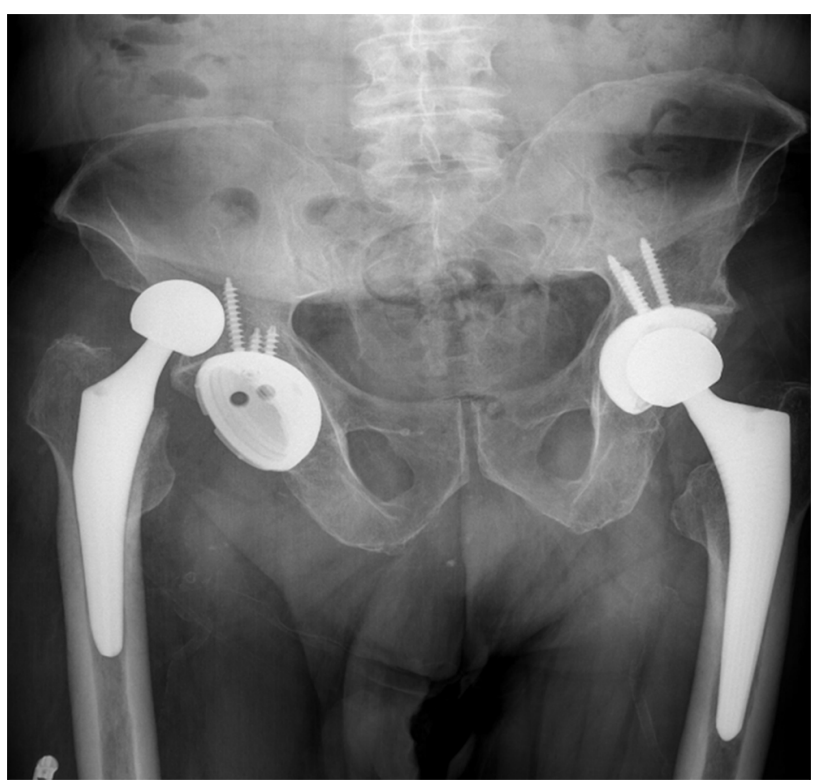

Şekil 3. Posterosuperiora doğru sağ kalça tekrarlayıcı dislokasyonu olan hastanın grafisi.

\section{TEKRARLAYICI DISLOKASYON (TEKRARLAYAN ÇIKIK)}

Literatürde TKA'dan sonra instabilite ve dislokasyon insidansları \%1 ile \%15 arasında bildirilmiştir. ${ }^{[18]}$ Küçük çaplı baş kullanımı, etekli baş kullanımı, yükseltilmiş kenarlı asetabular liner kullanımı ve bacak boyunun eşitlenememesi, dislokasyon riskini artıran nedenlerdendir (Şekil 3). ${ }^{[19]}$

Tekrarlayan çıkıkların en sık sebebi ise komponent hatalı pozisyonlarıdır. Cerrahi yaklaşım yeri ve cerrahın tecrübesi total kalça artroplastilerindeki stabiliteyi etkileyen en önemli faktördür. Yapılan bir çalışmada yılda 50'den az total kalça artroplastisi yapan cerrahların uygun asetabular komponent pozisyonunu kaçırma olasılığının 2,6 kat daha fazla olduğu gösterilmiştir. ${ }^{[20]}$

Literatürde asetabular komponent için 'güvenli bölge' tanımı yapılmıştır. ${ }^{[21]}$ Aşııı antevert yerleştirilmiş bir asetabulum ile öne çıkık olurken, aşırı retrovert pozisyonda posteriora doğru, inklinasyonu fazla bir asetabulumda ise adduksiyon hareketi ile lateral kalça çıkığı gelişir. Asetabular komponent yaklaşık $40^{\circ}$ ile $45^{\circ}$ arasında abduksiyonda ve $15^{\circ}$ ile $20^{\circ}$ arası anteversiyonda olmalıdır. Femoral komponent pozisyonlanmasında da anteversiyon ve retroversiyon açıları önem arz etmektedir. Uygun femoral anteversiyonu yaklaşık $15^{\circ}$ olarak konumlandırımalıdır. Ayrıca femoral offset yetersizliği de abduktor kol yetmezliği ve yumuşak doku gevşekliğine neden olup çıkık riskini artırır. Lakin kalça stabilitesi her iki komponent birlikte değerlendirilerek elde edilen 'kombine anteversiyon' ile sağlanmalıdır. ${ }^{[21]}$
Uygulanan cerrahi yaklaşım prosedürü de çıkık oluşmasında önemli bir etkendir. Posterior cerrahi yaklaşım ile \%3,2, direkt lateral yaklaşım ile \%0,6, anterolateral yaklaşım ile $\% 2,2$ ve direkt anterior yaklaşım ile $\% 0,6$ çıkık oranları bildirilmiştir. ${ }^{[22]}$

Haynes ve ark., yaptıkları çalışmada tekrarlayıcı dislokasyonu tüm revizyon cerrahileri içinde üçüncü en sık neden olarak belirtmişlerdir. Tekrarlayıcı dislokasyon olan 186 kalçadan \%89,2'sinin asetabular, \%4,8'inin femoral ve \%5,9'unun hem femoral hem de asetabular nedenli çıkığa yol açtığı görülmüştür. ${ }^{[6]}$

Yine çıkık oluşumuna; hastanın mevcut bir takım ek hastalıkları (vertebral patolojiler, nörolojik hastalıklar vb.), ameliyat öncesi kalça patolojisinin tanısı, yerleştirilen malzeme, eklem içi ve dışı impingement (sıkışma) gibi nedenler de etkili olabilir. Çıkık olguları kadın hastalarda daha sık görülmekte olup displazi hastalarının daha çok kadın cinsiyetten oluşması ve yumuşak doku desteğinin erkeklere oranla daha az olması buna neden olarak gösterilmiştir. Yaşla birlikte dislokasyon görülme insidansı da artmıştır, neden olarak ise ilerleyen yaşlarda nörokognitif fonksiyonların zayıflaması gösterilmiştir. ${ }^{[23]}$ Ayrıca; adale distrofisi ya da abduktor zayıflığı (geçirilmiş trokanter majör kırı̆̆ı vb.) olanlarda, psikoz, Parkinson, Alzheimer, serebral palsi, serebrovasküler hastalık öyküsü, alkolizm ve uyuşturucu bağımlılığı olan hastalarda çıkık insidansları fazladır. ${ }^{[24]}$

\section{PERIPROSTETIK KIRIK (PROTEZ ÇEVRESI KIRIK)}

Periprostetik kırık, total kalça artroplastisinin kısmen nadir ama ciddi bir komplikasyonu olup özellikle revizyon artroplastilerinden sonra sıklığı artmaktadır. Periprostetik kırıkların büyük bir kısmında cerrahi endikasyon bulunmaktadır. Protez çevresi kırıklardan sonra, kaynamama ve mobilizasyonun kısıtlanmasına bağlı olarak, özellikle ileri yaştaki hastalarda ek komplikasyonlar da daha sık olarak karşımıza çıkmaktadır. ${ }^{[25]}$

Asetabular bölge kırıklarının, çimentosuz komponentlerin kullanılmaya başlanmasıyla, çimentolu komponent kullanımına göre sıklığı daha da artmıştır. Bunlar genellikle asetabulum oyulurken görülmektedir. Asetabulum periprostetik kırıkları Peterson tarafından sınıflandırılmış olup tip 1'de stabil asetabular komponent mevcut iken, tip 2'de asetabular komponent instabildir. Ameliyat sırasında meydana gelen kırıklarda pelvik devamlılık korunuyorsa, stabilite yeterli ve pelvis kolonları sağlam ise kontrollü zamanlarda yük verme ile fazla implant kullanımına gerek olmadan bu kırıklar konservatif şekilde tedavi edilebilir. ${ }^{[26]}$ 

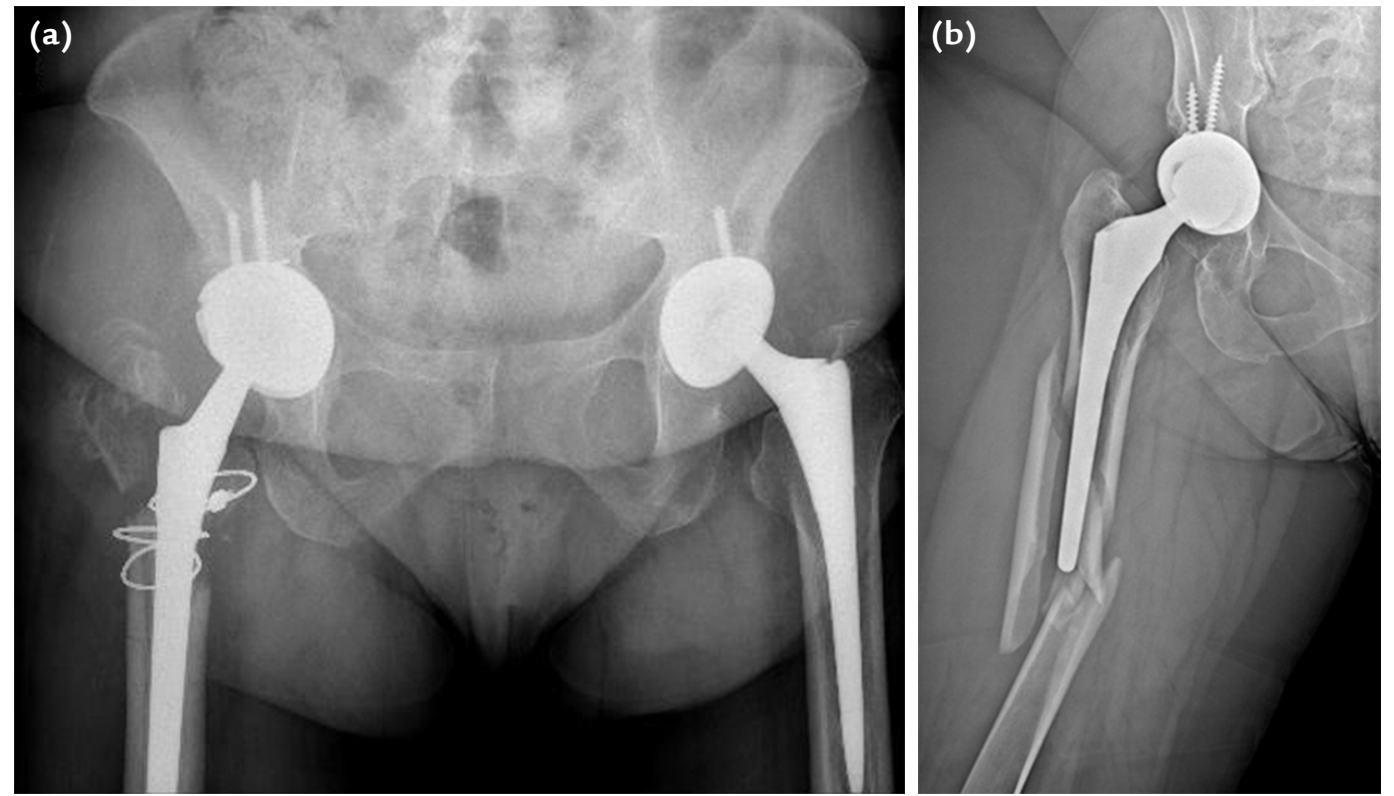

Şekil 4. a, b. Ameliyat esnasında periprostetik kırık üzerine serklaj teli ile tespit yapılan ancak sonrasında ise trokanter majör avülsiyon kırığı olan hasta (Vancouver Tip A) (a). Stem diyafizini de içine alan periprostetik kırık (Vancouver Tip B) (b).

Primer kalça artroplastisi esnasında çimentosuz femoral stemlerde kırık görülme oranı $\% 5,4$ olarak belirtilmişken bu oran çimentolu femoral stemlerde \%0,3 olarak bildirilmiştir. ${ }^{[27]}$ Ameliyat sırasındaki kırıklar femurun genellikle proksimalinde görülürken, kablo ya da serklaj uygulaması ya da erken yük vermeyi kısitlama ile tedavi ve takip edilebilir. Daha distalde ya da deplase kırık mevcut ve femoral stem stabil değilse revizyon protezi, plak ya da greft kullanımı endikasyonu gerekebilmektedir. Geç dönemde görülen periprostetik femur kırıklarını primer kalça artroplastisi sonrası $\% 1$, revizyon kalça artroplasti sonrası ise $\% 4$ oranında görülmektedir. Periprostetik kırıklarda yaygın olarak Vancouver sınıflaması kullanılmakta olup kırık yerine, komponent stabilitesine ve kemik kalitesine göre bu sınıflama yapılmaktadır. ${ }^{[27]}$ Vancouver Tip A kırıklar, proksimal metafizer kırıkları; Tip B kırıklar, diafizyel kırıkları; Tip C kırıklar, stemin distalindeki kırıkları tanımlamaktadır. Alt tiplendirmelerinde ise; 1 ) kortikal perforasyon, 2) nondeplase kırık, 3) deplase ve instabil kırık paternini tanımlar (Şekil 4). ${ }^{[28]}$

\section{IMPLANT KIRIĞI}

Kalça artroplastisi sonrası nadir görülen revizyon nedenlerindendir. ${ }^{[29]}$ Total kalça artroplasti uygulamalarında implant kırı̆̆ı seramik liner, seramik baş, polietilen (PE) liner, femoral stem ve metalik asetabular komponent kırıkları olarak karşımıza çıkabilir.
Seramik liner ve seramik baş kırıkları diğerlerine oranla daha sıktır. Majör travmalar sonrası olabildikleri gibi genellikle gündelik aktiviteler sırasında meydana gelir. ${ }^{[30]}$

Seramik liner kırığı için aşırı antevert asetabular komponent ve ilk yerleştirilme esnasında asimetrik konumlanan seramik liner en önemli iki mekanik risk faktörüdür. Aşırı antevert yerleştirilmiş asetabular komponent, boyun-kap sıkışmasına neden olur. Buna bağlı olarak femoral baş subluksasyonu gerçekleşir ve liner kenarında yüklenme artışına bağlı olarak kırıkla sonuçlanır. Aynı mekanizmanın, liner subluksasyonuna ve buna bağlı kırıklara da neden olduğu düşünülmektedir. Ayrıca obezite ve metal arkalıklı sandviç tipi seramik linerlar da seramik liner kırığı için risk oluşturur. ${ }^{[30]}$ Seramik femoral baş kırığı için kısa boyunlu $28 \mathrm{~mm}$ çaplı baş kullanımı seramik-seramik ve seramik-polietilen yüzeylerde bilinen tek risk faktörüdür.

Seramik kırığı tanısı konulduğunda, sert seramik parçaların sabit komponentlere zarar vermesini engellemek için geciktirmeden revizyon yapılmalıdır. Revizyonda geniş ve kapsamlı sinovektomi ve düşük basınçlı yıkama yapılmalıdır. Eğer kilitleme mekanizması zarar görmüşse veya malpozisyonda yerleştirilmiş bir asetabular komponent mevcutsa mutlaka değiştirilmelidir. Seramik-seramik veya seramik-polietilen yüzey seçenekleri üçüncü cisim aşınmasından korunmak için tercih edilebilir. ${ }^{[31]}$ 


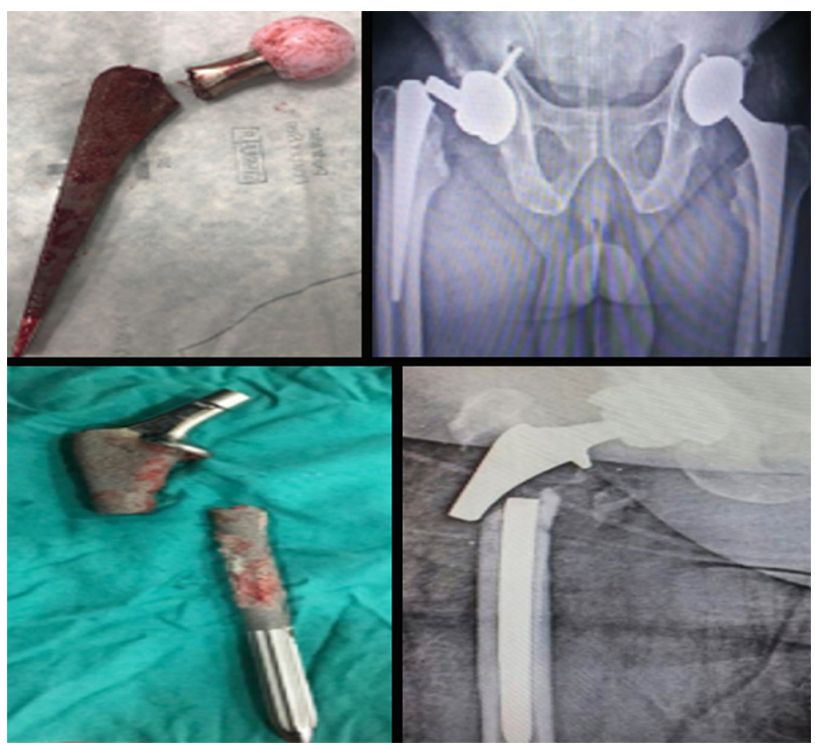

Şekil 5. Femoral stem kırı̆̆ı; implant ve radyografi örnekleri. (Op. Dr. İsmail Yükünç'ün kişisel arşivinden izin alınarak kullanılmıştır.)
Femoral stem kırılmaları daha çok eski tip stemlerde görülür. Şekil 5'te görülen yeni jenerasyon bir stem olup kırıklar genellikle daha önceki jenerasyonlarda olmaktadır. Stem kırığı genellikle boyun omuz geçiş bölgesinde metal yorgunluğuna bağı olarak gelişir. Proksimal medial femoral kemik defektleri (kalkar yetmezliği) özellikle distal tutulumlu stemler kullanıldığında önemli bir risk faktörüdür. Bunun dışında stem hatalı pozisyonu (varus-valgus), yüksek vücut kitle indeksi, yüksek aktivite düzeyi, küçük femoral stem ve kötü sementleme tekniği de diğer risk faktörlerini oluşturur (Şekil 5). ${ }^{[32]}$

Polietilen asetabular liner kırıkları çok nadir görülmekle beraber, özellikle aşırı vertikal yerleşimli asetabular komponentlerde ya da çimentolu PE linerların kullanıldığı ve çimentonun ince kaldığı bölgelerde, yük dağılımının değişmesine bağlı olarak veya kalça üzerine düşme gibi direkt travmaya sekonder olarak gelişmektedir. ${ }^{[33]}$ Metalik asetabular komponent kırıkları ise birkaç olgu takdiminden daha fazla sayıda değildir ve üretim kaynaklı sorunlara bağlı geliştikleri düşünülmektedir. ${ }^{[31]}$

\section{BACAK BOYU EŞiTSizLiĞi (BBE)}

Total kalça artroplastisi sonrası bacak boyu eşitsizli$\breve{g}$ i, hasta ve cerrah için memnuniyetsizlikle sonuçlanan önemli bir sorundur. Total kalça artroplastisi sonrası en sık hukuki şikâyet nedenlerindendir. ${ }^{[34]}$ Bacak boyu eşitsizliği yapısal veya fonksiyonel olabilir. Fonksiyonel eşitsizlikler pelvik oblisite, lumbosakral skolyoz ve kas kontraktürleri gibi nedenlere bağlı olup zaman

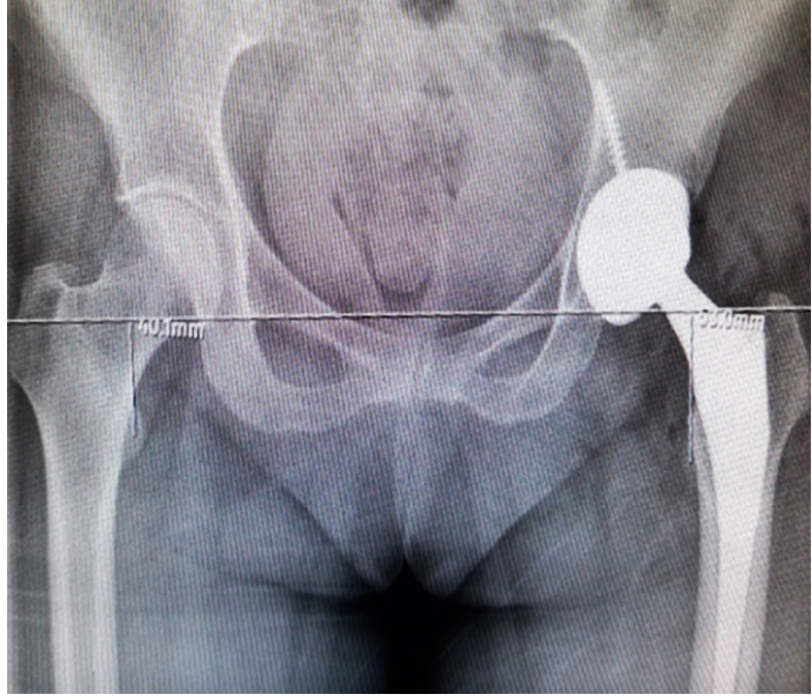

Şekil 6. Woolson metodunda gözyaşı figürlerinin alt noktalarını birleştiren çizgi referans alınarak her iki trokanter minörün orta noktasına olan uzaklık ölçülür.

içerisinde düzelebilir. Yapısal (gerçek) eşitsizlikler ise hatalı implant pozisyonuna bağlı oluşur. İmplantın hatalı pozisyonu iki nedenle BBE'ye neden olur ${ }^{[35,36] \text { : }}$ 1) Asetabular komponentin gözyaşı figüründen daha aşağıda veya femoral komponentin yüksekte yerleştirilmesi gibi durumlar BBE'ye direkt olarak etki eder. 2) Asetabular versiyon bozukluğu gibi instabiliteye neden olan durumlarda yumuşak doku gerginliğini sağlamak için femoral baş uzunluğu veya femoral offset değişikliği ise indirekt olarak BBE'ye yol açar.

Ameliyat öncesi planlama, ameliyat içinde doğru komponent seçimi, uygun komponent pozisyonlaması ve yeterli kas gevşemesinin sağlandığı anestezi yöntemleri kullanılarak BBE önlenebilir. Bacak boyu eşitsizliği radyolojik ölçümü için tarif edilmiş yöntemler vardır. Sıklıkla Woolson veya Williamson ve Reckling tarafından tarif edilen yöntemler kullanılır (Şekil 6). ${ }^{[37]}$

Hastaların büyük kısmı BBE'nin farkında değildir. Bacak boyu eşitsizliği topallama, yorgunluk, ağrı veya akut sinir hasarı klinikleri ile karşımıza çıkabilir. Kısalık genellikle uzunluktan daha iyi tolere edilir. Fonksiyonel BBE genellikle 6-12 ayda fizik tedavi ve kompansatuvar mekanizmalar ile asemptomatik hale gelebilir. Semptomatik gerçek BBE'de ise ilk olarak yükseltici tabanlık gibi konservatif yöntemler 6-12 ay kadar denenmelidir. Konservatif tedaviye cevap vermeyen ve hastanın hayat kalitesini düşüren şikâyetlerinin devam etmesi (ağrı, topallama), tekrarlayan instabiliteler (kısa ekstremitelerde) olması durumunda revizyon cerrahisine başvurulabilir. ${ }^{[35,36]}$ 


\section{METAL IYONLARINA KARŞI REAKSIYON VE ALERJi}

Biyomekanik olarak birçok avantaja sahip olan metal-metal TKA ve yüzey yenileme artroplastilerinde aşınma sonucu metal iyonları ve debris ortaya çıkar. Bu metal debrise karşı immunolojik yanıt sonucunda lokal doku reaksiyonları oluşabilir. Lokal doku reaksiyonlarının yanı sıra sistemik dolaşıma geçen metal iyonları vücudun diğer dokularında da (santral sinir sistemi ve iç organlarda) birikim yapabilir. ${ }^{[38]}$ Bu metal debrise karşı protez çevresinde lokal doku yanıtı kistik veya solid kitleler (psödotümör), metallozis ve ALVAL (aseptik lenfosit dominant vaskülit-ilişkili lezyon) olarak karşımıza çıkar. ${ }^{[39]}$ Psödotümör sıklığı, değişik kaynaklarda farklı oranlar belirtilmekle birlikte \%10-\%15 civarındadır. Metal-metal eklemleşmelerinde revizyonların yaklaşık yarısı ise bu lokal doku reaksiyonları veya psödotümöre bağlıdır. Risk faktörü olarak vertikal yerleşimli asetabular komponent ve kadın cinsiyet sayılabilir. ${ }^{[40]}$ Kliniği asemptomatik olabildiği gibi değişik düzeylerde kasık ağrısı ve topallama sıkça başvuru nedenlerindendir.

Fonksiyonel, ağrısız, serum iyon değerleri düşük olan ve radyolojik olarak US (ultrasonografi) veya MARS MRI (metal artifact reduction sequence magnetic resonance imaging) psödotümör olmayan metal-metal TKA konservatif olarak takip edilebilir. Serum iyon seviyesi 7 PPB'nin (milyardaki partikül sayısı) üzerinde, radyolojik olarak psödotümör tespit edilmiş ise revizyon cerrahisi düşünülmelidir. Revizyon cerrahisinde metalik debrise bağlı dokular mümkün olduğunca eksize edilmelidir. Revizyon cerrahisinde seramik üzeri polietilen yüzey eklemleşmesi önerilir. Revizyon cerrahisinden sonra abduktor yetmezlik ve instabilite, tekrarlayan metal reaksiyonları, enfeksiyon, aseptik gevşeme gibi komplikasyonlar oldukça sıktır. ${ }^{[41]}$

Eklem artroplasti cerrahisinde metal alerjisi (aşıı duyarlı|ı̆ı), sınırlı kanıta sahip çok tartışmalı bir konudur. İmplantasyon sonrası ilk iki yılda ağrı ve cilt lezyonları ile kendini gösterebilir. Tanıda cilt yama testi ve lenfosit transformasyon testleri kullanılabilir. Asıl tanı, şikâyete neden olabilecek diğer tüm olasılıkların dışlanması ile konulur. Metal alerjisinin tedavisinde hipo-alerjik implant kullanımı düşük kanıt düzeyine sahip bir tedavi şeklidir. ${ }^{[42]}$

\section{DIĞER FAKTÖRLER}

Seramik-seramik ve nadiren metal-metal yüzey eklemleşmelerinde bazı hastalarda yürüme esnasında veya hareketle kalça ekleminden ses çıkabilir. ${ }^{[43]}$ Bu ses gıcırtı şeklinde olabileceği gibi 'klik' şeklinde de olabilir. Klik sesi ile seramik-seramik yüzeylerde $\% 10-\% 23$ oranında ve gıcırdamadan daha sık karşılaşııır. ${ }^{[44]}$ Bu seslerin büyük bir kısmı ileri düzeyde rahatsızlık verecek seviyede değildir. Nedeni tam olarak bilinmemekle birlikte asetabular komponentin pozisyonu, impingement, seramik kırı̆̆ı, subluksasyon ve üçüncü cisim aşınması vb. ile ilgili olduğu düşünülmektedir. Bu sesler ağrıya neden oluyorsa, sürekli ve hastanın hayat kalitesini bozacak düzeyde ise revizyon cerrahisi gerekebilir. ${ }^{[45]}$ Trunniyoz metal baş boyun ara yüzündeki aşınmaya bağlı debris nedeniyle oluşan lokal doku reaksiyonlarını ifade eder. Bazı çalışmalara göre tüm revizyonların \%3'ünün sebebi olarak gösterilir. ${ }^{[46]} \mathrm{Bu}$ lokal doku reaksiyonları histolojik olarak metallozis ve psödotümörle aynıdır.

İliopsoas tendinozisi, TKA sonrası görülebilen kasık ağrısı nedenlerindendir. Genellikle uzun femur boyun kesisi, büyük, lateral yerleşimli ve anteriora taşması olan kaplar, osteofit irritasyonu, uzun asetabular vida irritasyonu veya çimentolu protelezlerde çimento irritasyonu sonucu oluşur. Konservatif tedaviye yanıt vermeyen olgularda genellikle tendonun cerrahi olarak gevşetilmesi yeterli olurken nadiren de olsa asetabular kap revizyonu gibi cerrahi girişimler de gerekebilir. ${ }^{[4]}$

\section{KAYNAKLAR}

1. Berry DJ, Harmsen WS, Cabanela ME, Morrey BF. Twentyfive-year survivorship of two thousand consecutive primary Charnley total hip replacements: factors affecting survivorship of acetabular and femoral components. J Bone Joint Surg Am 2002;84(2):171-7. Crossref

2. Corbett KL, Losina E, Nti AA, ProkopetzJJ, KatzJN. Populationbased rates of revision of primary total hip arthroplasty: a systematic review. PloS One 2010;5(10):e13520. Crossref

3. Clohisy JC, Calvert G, Tull F, McDonald D, Maloney WJ. Reasons for revision hip surgery: a retrospective review. Clin Orthop Relat Res 2004;429:188-92. Crossref

4. Ulrich SD, Seyler TM, Bennett D, Delanois RE, Saleh KJ, Thongtrangan I, Kuskowski M, Cheng EY, Sharkey PF, Parvizi J, Stiehl JB, Mont MA. Total hip arthroplasties: what are the reasons for revision? Int Orthop 2008;32(5):597-604. Crossref

5. Kelmer G, Stone AH, Turcotte J, King PJ. Reasons for revision: primary total hip arthroplasty mechanisms of failure. J Am Acad Orthop Surg 2021;29(2):78-87. Crossref

6. Haynes JA, Stambough JB, Sassoon AA, Johnson SR, Clohisy JC, Nunley RM. Contemporary surgical indications and referral trends in revision total hip arthroplasty: a 10-year review. J Arthroplasty 2016;31(3):622-5. Crossref

7. Moore KD, Beck PR, Petersen DW, Cuckler JM, Lemons JE, Eberhardt AW. Early failure of a cross-linked polyethylene acetabular liner: a case report. J Bone Joint Surg Am 2008;90(11):2499-504. Crossref

8. Dumbleton $\mathrm{JH}$, Manley MT, Edidin AA. A literature review of the association between wear rate and osteolysis in total hip arthroplasty. J Arthroplasty 2002;17(5):649-61. Crossref

9. Maloney WJ, Galante JO, Anderson M, Goldberg V, Harris WH, Jacobs J, Kraay M, Lachiewicz P, Rubash HE, Schutzer $\mathrm{S}$, Woolson ST. Fixation, polyethylene wear, and pelvic osteolysis in primary total hip replacement. Clin Orthop Relat Res 1999;369:157-64. Crossref 
10. Hu CY, Yoon T-R. Recent updates for biomaterials used in total hip arthroplasty. Biomater Res 2018;22(1):1-12. Crossref

11. Devane PA, Horne JG, Ashmore A, Mutimer J, Kim W, Stanley J. Highly cross-linked polyethylene reduces wear and revision rates in total hip arthroplasty: a 10-year doubleblinded randomized controlled trial. J Bone Joint Surg Am 2017;99(20):1703-14. Crossref

12. Bozic KJ, Rubash HE. The painful total hip replacement. Clin Orthop Relat Res 2004;420:18-25. Crossref

13. O'Neill DA, Harris WH. Failed total hip replacement: assessment by plain radiographs, arthrograms, and aspiration of the hip joint. J Bone Joint Surg Am 1984;66(4):540-6. Crossref

14. Tsukayama DT, Estrada R, Gustilo R. Infection after total hip arthroplasty. J Bone Joint Surg Am 1996;78(4):512-23. Crossref

15. Shahi AS, Parvizi J. The role of biomarkers in the diagnosis of periprosthetic joint infection. EFORT Open Rev 2016;1(7):275-8. Crossref

16. Schwarz EM, Parvizi J, Gehrke T, Aiyer A, Battenberg A, Brown SA, Callaghan JJ, Citak M, Egol K, Garrigues GE, Ghert M, Goswami K, Green A, Hammound S, Kates SL, McLaren AC, Mont MA, Namdari S, Obremskey WT, O'Toole R, Raikin S, Restrepo C, Ricciardi B, Saeed K, Sanchez-Sotelo J, Shohat N, Tan T, Thirukumaran CP, Winters B. 2018 International Consensus Meeting on Musculoskeletal Infection: Research Priorities from the General Assembly Questions J Orthop Res 2019;37(5):997-1006. Crossref

17. Toms A, Davidson D, Masri B, Duncan C. The management of peri-prosthetic infection in total joint arthroplasty. J Bone Joint Surg Br 2006;88-B(2):149-55. Crossref

18. Von Knoch M, Berry DJ, Harmsen WS, Morrey BF. Late dislocation after total hip arthroplasty. J Bone Joint Surg Am 2002;84(11):1949-53. Crossref

19. Nishii T, Sugano N, Miki H, Koyama T, Takao M, Yoshikawa H. Influence of component positions on dislocation: computed tomographic evaluations in a consecutive series of total hip arthroplasty. J Arthroplasty 2004;19(2):162-6. Crossref

20. Barrack RL, Krempec JA, Clohisy JC, McDonald DJ, Ricci WM, Ruh EL, Nunley RM. Accuracy of acetabular component position in hip arthroplasty. J Bone Joint Surg Am 2013;95(19):1760-8. Crossref

21. Lewinnek GE, Lewis J, Tarr R, Compere C, Zimmerman J. Dislocations after total hip-replacement arthroplasties. J Bone Joint Surg Am 1978;60(2):217-20. Crossref

22. Glassman $\mathrm{AH}$, Lachiewicz PF, Tanzer M; American Academy of Orthopaedic Surgeons; Hip Society (U.S.); Knee Society (U.S.). Orthopaedic knowledge update. Hip and knee reconstruction 4. American Academy of Orthopaedic Surgeons; 2011.

23. Sanchez-Sotelo J, Berry DJ. Epidemiology of instability after total hip replacement. Orthop Clin North Am 2001;32(4):54352. Crossref

24. Woolson ST, Rahimtoola ZO. Risk factors for dislocation during the first 3 months after primary total hip replacement. J Arthroplasty 1999;14(6):662-8. Crossref

25. Singh JA, Jensen MR, Lewallen DG. Patient factors predict periprosthetic fractures after revision total hip arthroplasty. J Arthroplasty 2012;27(8):1507-12. Crossref

26. Peterson CA, Lewallen DG. Periprosthetic fracture of the acetabulum after total hip arthroplasty. J Bone Joint Surg Am 1996;78(8):1206-13. Crossref

27. Duncan C, Masri BA. Fractures of the femur after hip replacement. Instr Course Lect 1995;44:293-304. https:// pubmed.ncbi.nlm.nih.gov/7797866/

28. Shah RP, Sheth NP, Gray C, Alosh H, Garino JP. Periprosthetic fractures around loose femoral components. J Am Acad Orthop Surg 2014;22(8):482-90. Crossref
29. Sadoghi P, Pawelka W, Liebensteiner MC, Williams A, Leithner A, Labek $\mathrm{G}$. The incidence of implant fractures after total hip arthroplasty. Int Orthop 2014;38(1):39-46. Crossref

30. Rambani R, Kepecs DM, Mäkinen TJ, Safir OA, Gross AE, Kuzyk PR. Revision total hip arthroplasty for fractured ceramic bearings: a review of best practices for revision cases. J Arthroplasty 2017;32(6):1959-64. Crossref

31. Sharma V, Ranawat AS, Rasquinha VJ, Weiskopf J, Howard $\mathrm{H}$, Ranawat CS. Revision total hip arthroplasty for ceramic head fracture: a long-term follow-up. J Arthroplasty 2010;25(3):342-7. Crossref

32. Köksal A, Öner A, Çimen O, Aycan OE, Akgün H, Yapıcı F, Çamurcu Y. Femoral stem fractures after primary and revision hip replacements: A single-center experience. Joint Dis Relat Surg 2020;31(3):557-63. Crossref

33. Blumenfeld TJ, McKellop HA, Schmalzried TP, Billi F. Fracture of a cross-linked polyethylene liner: a multifactorial issue. J Arthroplasty 2011;26(4):666.e5-e8. Crossref

34. Mancuso CA, Jout J, Salvati EA, Sculco TP. Fulfillment of patients' expectations for total hip arthroplasty. J Bone Joint Surg Am 2009;91(9):2073-8. Crossref

35. Parvizi J, Sharkey PF, Bissett GA, Rothman RH, Hozack WJ. Surgical treatment of limb-length discrepancy following total hip arthroplasty. J Bone Joint Surg Am 2003;85(12):2310-7. Crossref

36. McWilliams AB, Grainger AJ, O'Connor PJ, Redmond AC, Stewart TD, Stone MH. A review of symptomatic leg length inequality following total hip arthroplasty. Hip Int 2013;23(1):6-14. Crossref

37. Woolson ST, Hartford JM, Sawyer A. Results of a method of leg-length equalization for patients undergoing primary total hip replacement. J Arthroplasty 1999;14(2):159-64. Crossref

38. Bozic KJ, Kurtz SM, Lau E, Ong K, Vail TP, Berry DJ. The epidemiology of revision total hip arthroplasty in the United States. J Bone Joint Surg Am 2009;91(1):128-33. Crossref

39. Kocaoğlu H, Başarır K, Erdemli B. Total kalça artroplastisinde eklemleşme seçenekleri: Eklemleşme kime, hangi ikili? TOTBID Derg 2013;12(3):239-47. Crossref

40. Williams DH, Greidanus NV, Masri BA, Duncan CP, Garbuz DS. Prevalence of pseudotumor in asymptomatic patients after metal-on-metal hip arthroplasty. J Bone Joint Surg Am 2011;93(23):2164-71. Crossref

41. Lombardi Jr AV, Barrack RL, Berend KR, Cuckler JM, Jacobs JJ, Mont MA, Schmalzried TP. The Hip Society: algorithmic approach to diagnosis and management of metal-onmetal arthroplasty. J Bone Joint Surg Br 2012;94-B(11_ Supple_A):14-8. Crossref

42. van der MerweJM. Metal Hypersensitivity in Joint Arthroplasty. JAAOS Global Res Rev 2021;5(3):e20.00200. Crossref

43. Brockett CL, Williams S, Jin Z, Isaac GH, Fisher J. Squeaking hip arthroplasties: a tribological phenomenon. J Arthroplasty 2013;28(1):90-7. Crossref

44. Kim Y-H, ParkJ-W. Eighteen-year follow-up study of 2 alternative bearing surfaces used in total hip arthroplasty in the same young patients. J Arthroplasty 2020;35(3):824-30. Crossref

45. Walter WL, Jenabzadeh R, Reinhardt C. Clinical Management of hip Arthroplasty: Practical Guide for Handling Noises in Hard-on-Hard Bearings: Springer; 2015. Crossref

46. Mistry JB, Chughtai M, Elmallah RK, Diedrich A, Le S, Thomas M, Mont MA. Trunnionosis in total hip arthroplasty: a review. J Orthop Traumatol 2016;17(1):1-6. Crossref

47. O'Sullivan M, Tai CC, Richards S, Skyrme AD, Walter WL, Walter WK. Iliopsoas tendonitis: a complication after total hip arthroplasty. J Arthroplasty 2007;22(2):166-70. Crossref 